tional law. The most interesting part of this chapter concerns the fundamental problems of international procedural law in its comparative aspect.

The final parts of the book concern the legal quality of resolutions (Mr. Rosenne denies the existence of direct binding force of such resolutions) and of doctrine in the formation of international law.

Władyslaw Czapliński

\title{
Paul Sieghart
}

\section{The International Law of Human Rights}

Oxford University Press, 1984, 117.50

The problem of international legal protection of human rights has recently been very popular among international lawyers, and the number of publications in this field still increases. These publications are of very varying character: some of them concern special questions while others are relatively complex and illustrate the progressive development in the field of international law of human rights. No author would be able to refer to all works concerning this problem, inter alia because of language difficulties and Paul Sieghart has not had such ambitions. He has tried to present the actual situation in the field of international protection of human rights, taking into account norms and solutions adopted in international instruments on human rights.

The author has divided his work into four parts. The first one is of an introductory character and concerns the development of the concept of human rights in international and municipal law, the origin of respective human rights acts in international law and, finally, some fundamental problems of the law of treaties and of the application of international law within the internal legal orders. This part of the work seems not to be necessary and certainly it is not exhaustive. For example, the author touched briefly the problem of so-called self-executing treaties in international law (at p. 41) - yet it would be useful to consider to what extent human rights instruments are and could be self-executing. In my opinion human rights treaties seldom are self-executing and normally require transformation - this is one important reason for non-implementation of international legal obligations in this field. The respective states invoke a raison d'état to justify non-compliance with human rights acts; they maintain that states only, non individuals, are the subjects of international law and according to the principle of state sovereignty they preserve full freedom of action in internal affairs. Those assertions have been affirmed in several human rights acts, including the two Covenants of 1966. Finally it must be pointed out that some important problems have been totally omitted by the author: one may mention here the problems of universalism and regionalism in human rights (especially the alleged reurocentrism`) which seem to be extremely important and 
the question of to what extent non-binding acts (like e. g. General Assembly resolutions) can influence and give rise to international customary rules.

It is also a pity that Paul Sieghart did not try to consider the problem of relations between international law and internal laws of those states which violate human rights at nearly every step. In passing, one can note that in explaining the problems of relations between international law and municipal law, one cannot treat in the same way the solutions adopted in France and in the Federal Republic of Germany as the author does (at p. 41). The French constitution assures the absolute primacy of international law while according to article 25 of the West German Basic Law (constitution) the primacy only of the general principles of international customary law has been guaranteed; the position of international agreements within the legal system of the FRG is defined by the transformation law (Zustimmungsgesetz).

I would emphasize that my remarks are mostly of a doctrinal character. The author has stressed that he is a practitioner and that he wants to analyse the respective rights and norms of international instruments in their interactions. Mr. Sieghart has quoted the texts of respective sections of those instruments, adding very short comments concerning each right. Such approach seems to be correct, especially taking into account the fact that the implementation of rights remains in the exclusive domestic competence of respective states and the scope of rights and freedoms concerning the same basic right can be different in different States. Expecially interesting are the author's remarks on the social rights and so called "rights of third generation": Sieghart formulates in this context some remarks de lege ferenda rather than de lege lata; he recognizes the collective character of certain rights, like the protection of minorities which is still considered as the protection of individuals belonging to minorities, according to recent UN experiences of the late 1970s.

I would emphasize also the achievement of the author in analysing the parties to the respective agreements and reservations made (unfortunately no conclusions have been presented) while quoting judicial practice concerning the human rights.

The book by Paul Sieghart is a valuable compilation of sources of international law of human rights; those who expect any broader doctrinal analyse would, however, probably be disappointed.

Wtadyslaw Czaplinski 